\title{
Wheat Streak Mosaic: A Classic Case of Plant Disease Impact on Soil Water Content and Crop Water-Use Efficiency
}

\author{
F. Workneh, J. A. Price, D. C. Jones, and C. M. Rush, Texas AgriLife Research, Amarillo, TX 79106
}

The role of soil water (or soil matric potential) in plant disease development is a well-documented phenomenon, especially in diseases caused by soilborne plant pathogens $(7,11,14,19)$. For many plant pathogens, wet soil conditions or high soil matric potential promote hyphal growth, reproduction, spore dispersal, infection, and disease development (3,5-7,9-11). In sharp contrast to the abundance of information on the effect of soil water content on various plant diseases, the effect of plant diseases on soil water status and crop water-use efficiency is not well described. The significance of this effect may be less apparent in dryland agricultural production where rainfall is the only source of soil water; however, the effect has tremendous implications for irrigated agriculture in light of the dwindling water resources and the high cost of irrigation water (15-17). Plant diseases interfere with water intake $(8,12)$, suggesting that there should be a greater amount of surplus water in diseased areas than in healthy areas of the field. If this is indeed the case, water-use efficiency would be low in diseased crops, and expenses associated with addition of more water (when in fact there is surplus water still in the soil) is a cost which could potentially be avoided. The implications of a plant disease effect on crop water-use efficiency is more significant for diseases which have characteristic patchy distribution, where large areas of the field are affected, than in sporadically infected plants which may not be amenable to sitespecific management.

In this article, we describe the relationship between wheat streak mosaic (WSM) severity and soil water content as a prime example of the effect of a plant disease on soil water status and its implications for irrigated agriculture. Wheat streak mosaic virus (WSMV) is vectored by wheat curl mites (Aceria tosichella Keifer), which are typically blown into the field from nearby grasslands or fields with mite-infested

Corresponding author: F. Workneh
E-mail: f-workneh@tamu.edu

Accepted for publication 19 August 2009.

doi:10.1094/PDIS-94-6-0771

(C) 2010 The American Phytopathological Society volunteer wheat $(4,20)$. WSM often exhibits severity gradients affecting over half of the field, with the heaviest infection toward the edges of the field (22). The disease is prevalent throughout the Texas Panhandle and much of the southwestern United States and is sometimes severe, drastically reducing both forage and grain yield $(2,22)$. Infected plants exhibit symptoms ranging from chlorotic streaking and mosaic to complete chlorosis of leaves and stunting of the plants (20).

A recent greenhouse study showed that plants infected with WSMV have poor root development and reduced water-use efficiency compared with uninfected plants (18). If diseased wheat cannot use water as efficiently as healthy wheat, blanket applications of irrigation water without recognizing specific requirements in different parts of the field is certainly an inefficient use of water. Diseased areas of the field are often infested with weeds because diseased plants cannot compete well with the weeds, and the unused soil moisture gets depleted by the weeds. If infected fields
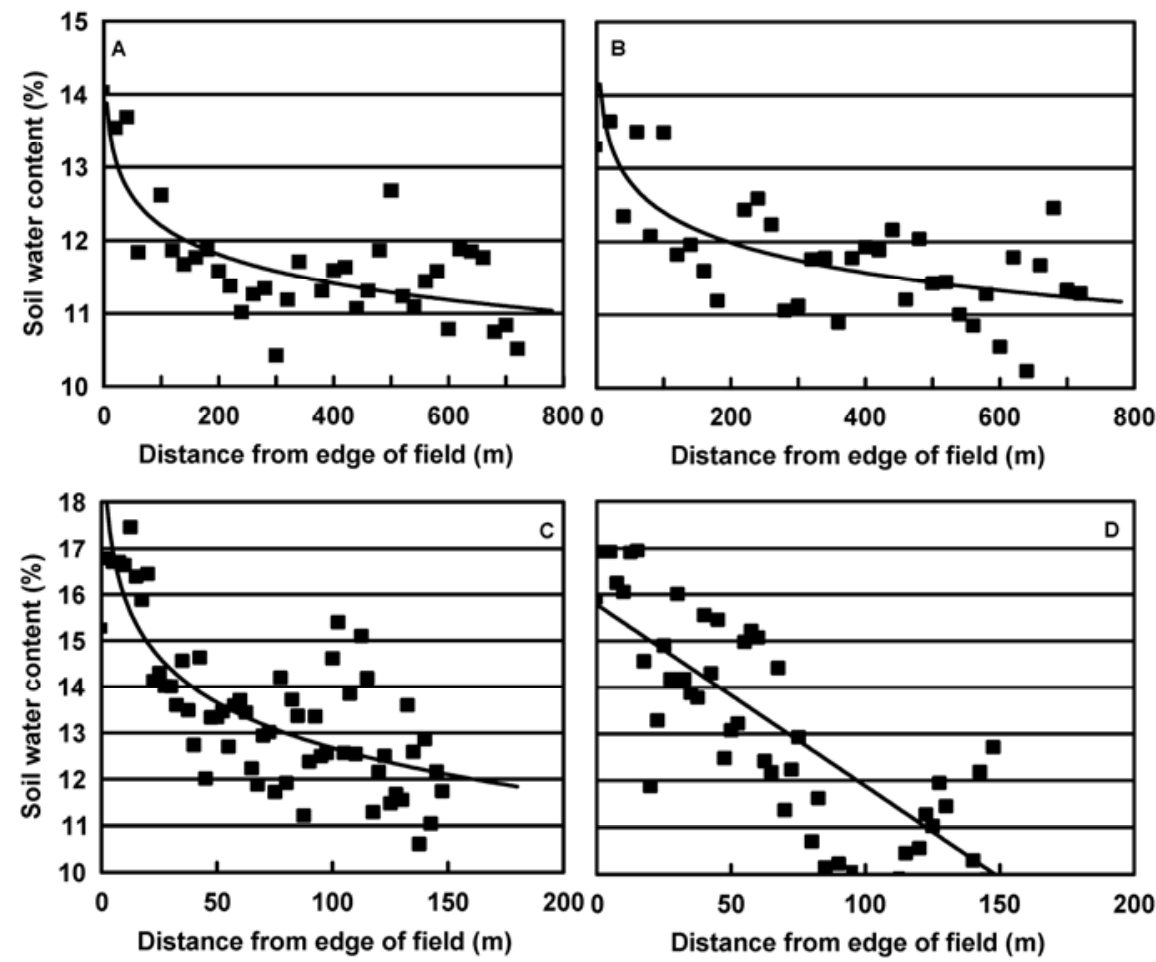

Fig. 1. Relationships between soil water content and distance from the edge of the field for two transects each in A and B, 2006 and $\mathbf{C}$ and D, 2007. have greater soil water and lower wateruse efficiency than healthy fields, they don't need as much water as healthy fields. This information can be vital to growers in making decisions whether to minimize or avoid water application depending on the disease severity. In light of rising energy costs, growers often question whether it is worthwhile to continue to irrigate fields affected with WSMV because information on the effect of the disease on crop water use is not available. In order to address this question, we conducted studies in growers' fields to characterize the relation between wheat streak severity, soil water content, and water-use efficiency.

\section{MATERIALS AND METHODS}

The present study was part of a larger investigation which included modeling of wheat yield as a function of WSM severity, conducted in one irrigated field in 2006 and two fields (irrigated and nonirrigated) in 2007 (22). Only the two irrigated fields are considered here because of the greater significance of WSM impact on crop wa- 
ter-use efficiency in irrigated systems. In the 2006 field, four transects (oriented in the same direction and $720 \mathrm{~m}$ long) were established across the field, each containing 37 sampling locations at $20-\mathrm{m}$ intervals. The 2007 field consisted of two transects each, having 60 sampling locations separated by $2.5-\mathrm{m}$ intervals. At each location, the severity of wheat streak in a $1-\mathrm{m}^{2}$ area (five rows in width) was quantified with reflectance measurements (remote sensing) using a hyperspectral, hand-held radiometer at $555 \mathrm{~nm}$ at Feekes growth stage 7-8 (13). In a preliminary study, reflectance measurements taken at this wavelength showed a high correlation with visual WSM severity assessments (unpublished). Diseased leaf samples from each
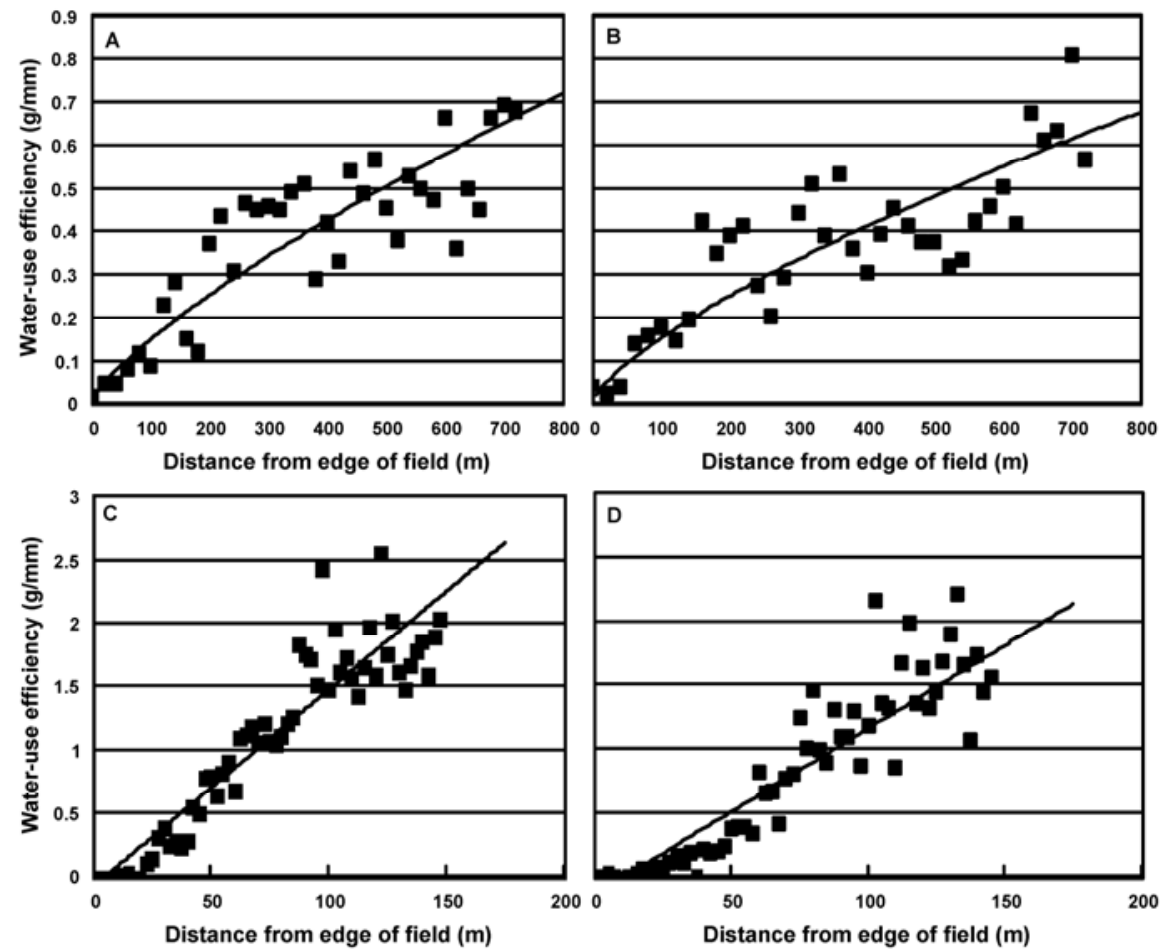

Fig. 2. Relationships between water-use efficiency for yield and distance from the edge of the field for two transects each in $\mathbf{A}$ and $\mathbf{B}, 2006$ and $\mathbf{C}$ and $\mathbf{D}, 2007$.
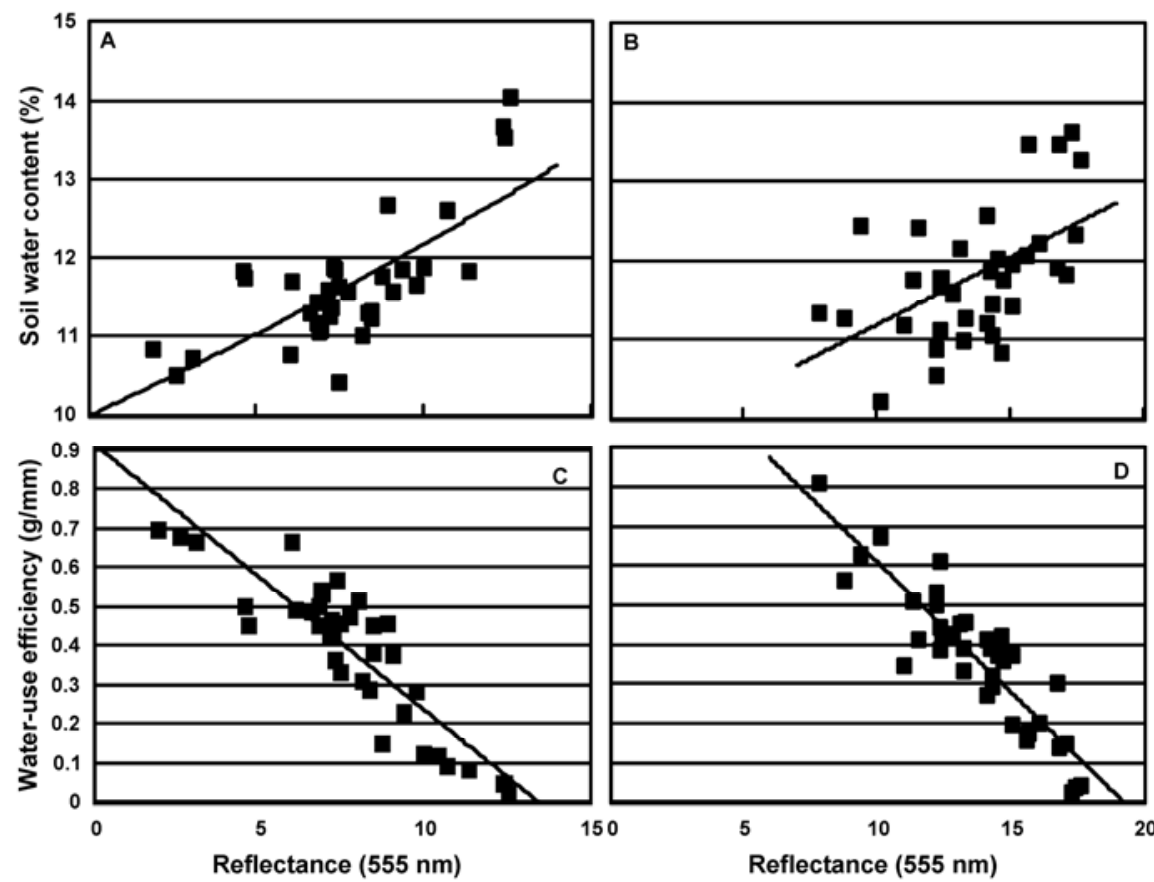

Fig. 3. Relationships between $\mathbf{A}$ and $\mathbf{B}$, wheat streak mosaic severity, as measured by reflectance at $555 \mathrm{~nm}$ wavelength, and soil water content in 2006 from two transects; and between $\mathbf{C}$ and $\mathbf{D}$, wheat streak mosaic severity and water-use efficiency for yield in the two transects. location were collected and tested by double-antibody sandwich enzyme-linked immunosorbent assay to verify that the symptoms were caused by WSMV. Soil water content at each location was determined gravimetrically from a $4.6-\mathrm{cm}-$ diameter core from 0 to $0.9 \mathrm{~m}$ in depth. The wet weight of each soil sample was determined immediately after sampling. Soil samples then were dried for $48 \mathrm{~h}$ at $105^{\circ} \mathrm{C}$, and soil water content was calculated as the difference between wet and dry weight. The amount of irrigation water added from planting to data collection was obtained from growers' records. Wheat from a $0.8-\mathrm{m}^{2}$ area at each location was harvested and grain yield determined. Aboveground tissue dry weight was determined from a $0.2-\mathrm{m}^{2}$ area (one row) at each location after drying at $75^{\circ} \mathrm{C}$ for 2 weeks. Water-use efficiency was expressed as a ratio of grain yield, or tissue dry weight, to the amount of irrigation water added (12). Details of the sampling procedures and the relationship between wheat streak severity and grain yield across the fields were reported previously (22). Data were analyzed using linear or nonlinear regression, whichever fitted best.

\section{RESULTS AND DISCUSSION}

Over $90 \%$ of the wheat leaf samples collected from locations along the transects tested positive for WSMV. For the 2006 field, because all transects showed similar disease trends across the field (22), only data from the first two (adjacent) transects are reported here. In both the 2006 and 2007 fields, soil water content declined with increasing distance from the edge of the fields (Fig. 1A-D). The water content declined curvilinearly in all transects $\left(R^{2}=\right.$ $0.47,0.46$, and $0.61, P<0.0001$ for the first, second, and third transect, respectively; Fig. 1A-C) except in the second transect of the 2007 field, in which there was a linear decline $\left(R^{2}=0.62, P<\right.$ 0.0001; Fig. 1D). Overall, differences in soil water content between the beginning and the end of the transects ranged from 3 to $7 \%$. In both years, water-use efficiency for yield strongly correlated with distance from the edge of the field. For the 2006 field, water-use efficiency increased curvilinearly with increasing distance from the edge of the field $\left(R^{2}=0.84\right.$ and $0.81, P<$ 0.0001 for the first and second transects, respectively; Fig. 2A and B), whereas the increase was linear for both transects of the 2007 field $\left(R^{2}=0.84\right.$ and $0.87, P<$ 0.0001 , for the first and second transects, respectively; Fig. 2C and D). The increase in water-use efficiency was associated with the decline in WSM severity as quantified by reflectance (22).

In both transects in the 2006 field, there were positive linear relationships between WSM severity $\left(R^{2}=0.55\right.$ and $0.28, P<0.0001$; Fig. $3 \mathrm{~A}$ and $\mathrm{B}$, respectively) and soil water content, indicating 
that severely diseased areas of the field had greater soil water content than the less severe or healthy areas of the field. Also, in both transects, water-use efficiency for grain yield exhibited a high negative correlation with WSM severity $\left(R^{2}=0.80\right.$ and $0.81, P<0.0001$; Fig. 3C and $\mathrm{D}$, respectively).

Data from the 2007 field showed results similar to those of 2006. However, in both transects, relationships between soil water content and wheat streak severity were curvilinear instead of linear as in $2006\left(R^{2}\right.$ $=0.51$ and $0.62, P<0.0001$; Fig. $4 \mathrm{~A}$ and $\mathrm{B}$, respectively). In both transects, there were also strong negative curvilinear relationships between WSM severity and water-use efficiency for yield. Water-use efficiency declined exponentially with increasing WSM severity $\left(R^{2}=0.89\right.$ and $0.82, P<0.0001$; Fig. $4 \mathrm{C}$ and $\mathrm{D}$, respectively, for both transects).

In all transects, water-use efficiency for tissue dry weight also followed a trend similar to that for yield in its relationship with WSM severity. For the 2006 data, water-use efficiency exhibited a strong negative correlation with WSM severity $\left(R^{2}=0.65\right.$ and $0.78, P<0.0001$; Fig. $5 \mathrm{~A}$ and $\mathrm{B}$, respectively, for both transects). There was also a strong negative relationship between the two variables in 2007 in both transects $\left(R^{2}=0.80\right.$ and $0.71, P<$ 0.0001; Fig. 5C and D, respectively). Water-use efficiency declined exponentially with increasing WSM severity.

These field studies clearly demonstrated that WSM indirectly affects water status of the soil by reducing crop water-use efficiency for grain yield and tissue dry weight. The magnitude of the effect depended on the severity of the disease in that variations in water status of the soil and water-use efficiency were largely explained by variations in disease severity. This study corroborated the findings by Price et al. (18) in greenhouse studies which showed that plants infected by WSMV have significantly less root and shoot biomass than noninfected plants, and water-use efficiency was significantly reduced in infected plants. Thus, it can be deduced that infected plants along the disease gradients in the fields also had gradients in root biomass corresponding to the disease severities at each location. Infected plants likely failed to develop extensive root systems (thus, less root biomass) for water intake, which resulted in greater soil water content.

Surveys conducted over the past several years have shown that WSM is the predominant virus disease in the Texas Panhandle (21). In some years, disease prevalence was so high that WSMV could be detected in almost every field in the region. For example, in 2006, $98 \%$ of the 130 wheat samples submitted to the Plant Disease Diagnostic Laboratory in Amarillo tested positive for WSMV. The Texas Pan- handle annually produces about half of the wheat production in the state of Texas on over 1 million ha, of which approximately one-third are irrigated (1). The magnitudes of irrigated fields and the disease prevalence in the region suggest that water is not efficiently used in wheat production. In current irrigation practices, irrigation water
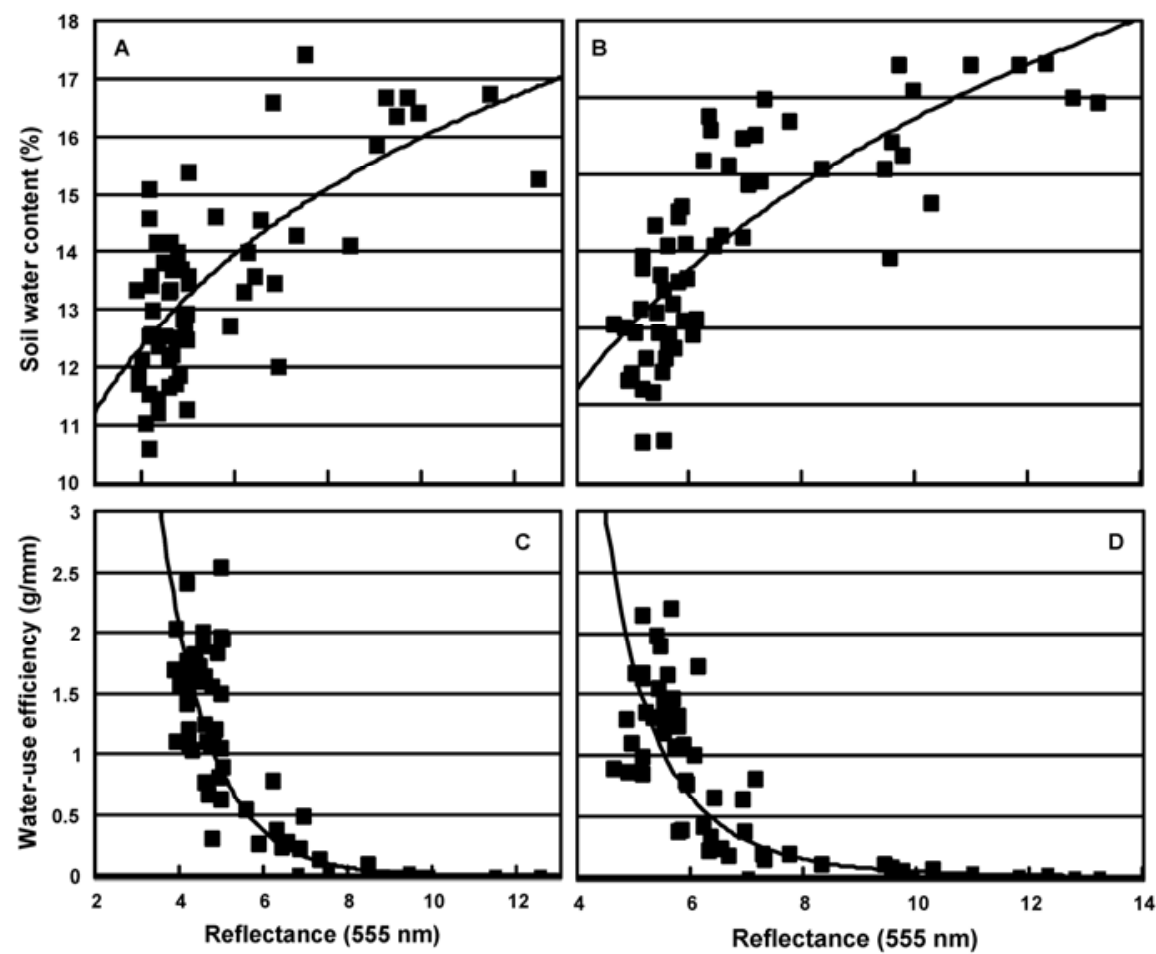

Fig. 4. Relationships between $\mathbf{A}$ and $\mathbf{B}$, wheat streak mosaic severity, as measured by reflectance at $555 \mathrm{~nm}$ wavelength and soil water content in 2007 from two transects; and between $\mathbf{C}$ and D, wheat streak mosaic severity and water-use efficiency for yield in the two transects.
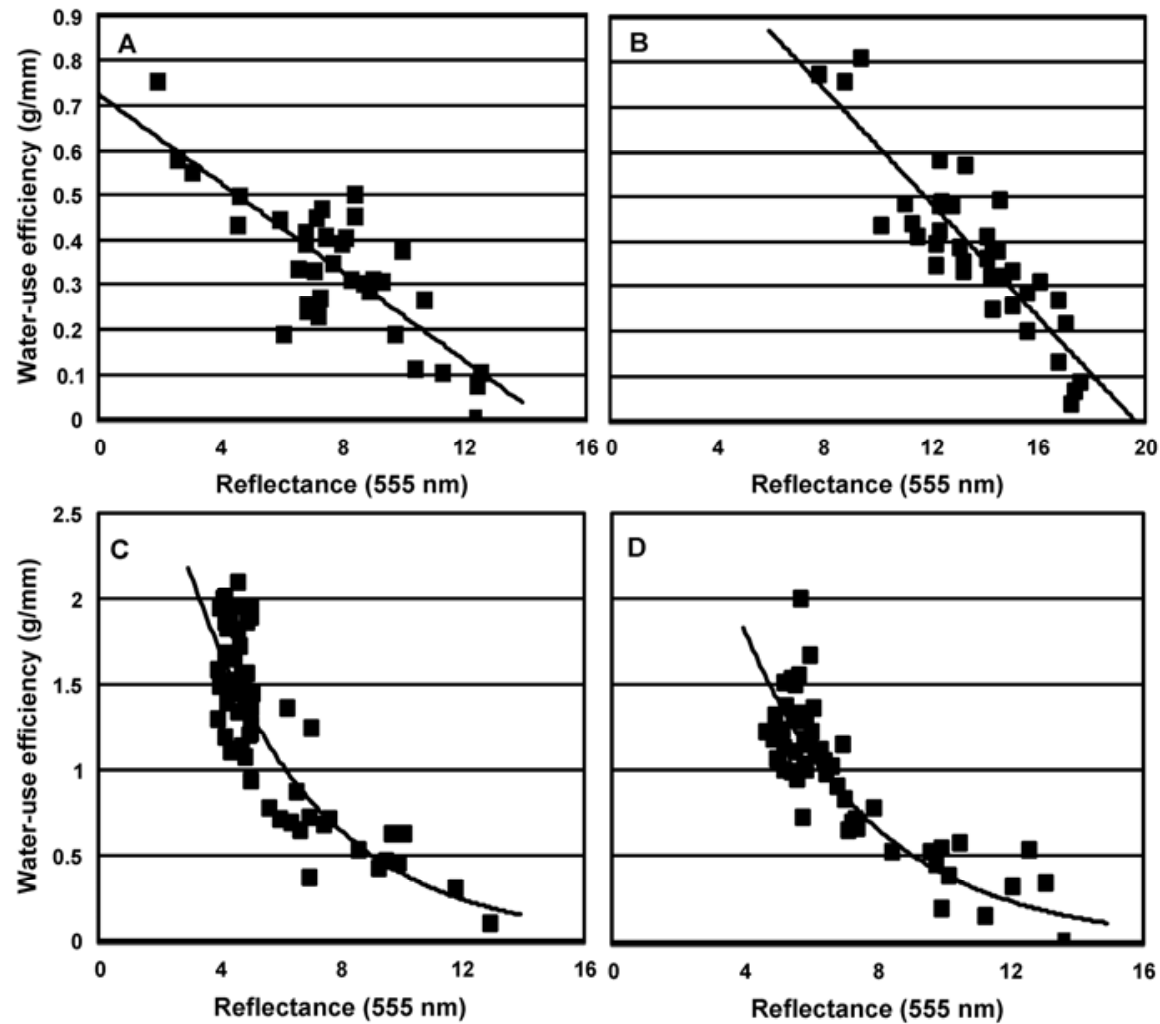

Fig. 5. Relationships between wheat streak severity mosaic, as measured by reflectance at $555 \mathrm{~nm}$ wavelength, and water-use efficiency for aboveground tissue dry weight from two transects each in $\mathbf{A}$ and $\mathbf{B}, 2006$ and $\mathbf{C}$ and $\mathbf{D}, 2007$. 
is applied to the entire field regardless of wheat streak intensity. However, advances in irrigation technology have now made it possible to use variable irrigation rate application practices with GPS-guided systems. As the technology becomes commercially available, growers may be able to avoid or minimize unnecessary applications of water in parts of the field considered less cost effective. As shown in this study, the disease is usually severe at the edge of the fields and progressively declines inward. Therefore, it is feasible that disease-severity thresholds can be established at locations along the gradients beyond which water application can be minimized or avoided using site-specific irrigation practices.

\section{ACKNOWLEDGMENTS}

The project was supported in part by the Ogallala Aquifer Program, a consortium between the United States Department of AgricultureAgricultural Research Service, Kansas State University, Texas AgriLife Research, Texas AgriLife Extension Service, Texas Tech University, and West Texas A\&M University.

\section{LITERATURE CITED}

1. Anonymous. 2006. Texas Agricultural Statistics. Texas Agricultural Statistics Service, Texas Department of Agriculture, Austin.

2. Atkinson. T. G., and Grant, M. N. 1967. An evaluation of streak mosaic losses in winter wheat. Phytopathology 57:188-192.

3. Carlile, J. M. 1983. Motility, taxis and tropism in Phytophthora. Pages 95-107 in: Phytophthora: Its Biology, Taxonomy, Ecology, and Pathology. D. C. Erwin, S. BartnickiGarcia, and P. H. Tsao eds. American Phytopathological Society, St. Paul, MN.

4. Christian, M. L., and Willis, W. G. 1993. Survival of Wheat streak mosaic virus in grass hosts in Kansas from wheat harvest to fall wheat emergence. Plant Dis. 77:239-242.

5. Cook, R. J., and Duniway, J. M. 1981. Water relations in the life-cycles of soilborne plant pathogens. Pages 119-139 in: Water Potential Relations in Soil Microbiology. Soil Science Society of America, Madison, WI.

6. Cook, R. J., and Papendick, R. I. 1970. Soil matric potential as a factor in the ecology of Fusarium roseum f. sp. cerealis 'Culmorum'. Plant Soil 32:131-145.

7. Duniway, J. M. 1975. Formation of sporangia by Phytophthora drechsleri in soil at high soil matric potentials. Can. J. Bot. 53:12701275 .

8. Duniway, J. M. 1977. Changes in resistance to water transport in safflower during the development of Phytophthora root rot. Phytopathology 67:331-337.

9. Duniway, J. M. 1979. Water relations of water molds. Annu. Rev. Phytopathol. 17:431-460.

10. Duniway, J. M. 1983. Role of physical factors in development of Phytophthora diseases. Pages 175-187 in: Phytophthora: Its Biology, Taxonomy, Ecology, and Pathology. D. C. Erwin, S. Bartnicki-Garcia, and P. H. Tsao eds. American Phytopathological Society, St. Paul, MN.

11. Harris, R. F. 1981. Effect of water potential on microbial growth and activity. Pages 23-96 in: Water Potential Relations in Soil Microbiology. Spec. Publ. no. 9, Soil Science Society of America. Madison, WI.
12. Kramer, P. J., and Boyer, J. S. 1995. Water Relations of Plants and Soils. Academic Press, New York.

13. Large, E. 1954. Growth stages in cereals: illustrations of the Feeke's scale. Plant Pathol. 3:128-129.

14. Livne, A., and Daly, J. M. 1966. Translocation in healthy and rust-affected beans. Phytopathology 56:170-175.

15. McGuire, V. L. 2006. Water-level changes in the High Plains aquifer, predevelopment to 2005 and 2003 to 2005. USGS Scientific Investigation Report 2006-5324.

16. New, L. 2006. Agripartner Irrigation Result Demonstration. Texas Cooperative Extension Service, Amarillo.

17. Postel, S. L. 1998. Water for food production: will there be enough in 2025? Bioscience 48:629-637.

18. Price, J. A., Workneh, F., Evett, S., Jones, D. C., Arthur, J., and Rush, C. M. 2010. Effects of Wheat streak mosaic virus on root development and water-use efficiency of winter wheat. Plant Dis. 94:766-770.

19. Rotem, J., and Palti, J., 1969. Irrigation and plant diseases. Annu. Rev. Phytopathol. 7:267288.

20. Wiese, M. V. 1987. Wheat streak mosaic. Pages 80-81 in: Compendium of Wheat Disease, 2nd ed. American Phytopathological Society, St. Paul, MN.

21. Workneh, F., Jones, D. C., Heidel, G. B., Price, J. A., and Rush, C. M. 2008. Surveys of whea viruses in the Texas Panhandle. (Abstr.) Phytopathology 98:S173.

22. Workneh, F., Jones, D. C., and Rush, C. M. 2009. Quantifying wheat yield across the field as a function of wheat streak mosaic intensity: a state space approach. Phytopathology 99: 432-440. 